\title{
Gonad development and spawning of the Vulnerable commercial sea cucumber, Stichopus herrmanni, in the southern Great Barrier Reef
}

\author{
REGINA BALOGH ${ }^{1}$, KENNEDY WOLFE ${ }^{1}$ AND MARIA BYRNE ${ }^{1,2}$ \\ ${ }^{1}$ School of Medical Sciences, The University of Sydney, Sydney, NSW 2006, Australia, ${ }^{2}$ School of Biological and Environmental \\ Sciences, The University of Sydney, Sydney, NSW 2006, Australia
}

\begin{abstract}
Despite the important ecological roles of commercial bêche-de-mer holothuroids in coral reef ecosystems their reproductive biology is poorly studied, including on the Great Barrier Reef (GBR). We investigated reproduction of Stichopus herrmanni, a commercially important species listed as Vulnerable, at One Tree Island, southern GBR. Gonad index, histology and spawning observations indicated an annual reproductive cycle with gamete release in the Austral spring and summer (NovemberFebruary), as for populations of this species at a similar latitude in New Caledonia. Stichopus herrmanni releases gametes episodically, spawning multiple times during summer. Assimilation of spawning observations from OTI and elsewhere along the GBR and tropical Pacific revealed that gamete release by S. herrmanni is influenced by the lunar cycle, with spawning taking place around the new moon in summer. This species is an aggregative spawner with a behavioural change to attain elevated positions on the reef at dusk prior to spawning. After the spawning season, gametes remaining in the gonads are reabsorbed. Spent gonads completely lacked gametes. There was a quiescence in gonad development in winter with an absence of gonads in some specimens, indicating an aestivation-like period for reproduction. By late-winter (August) recovery stage gonads were distinguished by the initiation of gametogenesis, which coincided with increasing temperature and day length. Our findings contribute to the understanding of the reproductive biology of S. herrmanni, a consideration for future fisheries management in the protection of this Vulnerable species, especially with respect to the increasing global trade in bêche-de-mer.
\end{abstract}

Keywords: Holothuroidea, reproduction, bêche-de-mer, curryfish, overfishing

Submitted 20 November 2017; accepted 16 January 2018; first published online 12 March 2018

\section{INTRDDUCTION}

Aspidochirotid holothuroids are a conspicuous component of the macro-benthos of marine environments. As deposit feeders, they process vast quantities of sediment, and thus play an important role in the mineralization and cycling of nutrients in benthic habitats (Uthicke \& Klumpp, 1998; Uthicke, 1999, 2001; Purcell et al., 2016; Lee et al., 2017). The release of nitrogenous waste by aspidochirotids can increase the productivity of benthic microalgae and seagrass systems, a particularly important functional role in oligotrophic coral reef ecosystems (Uthicke \& Klumpp, 1998; Uthicke, 2001; Eriksson et al., 2010; Wolkenhauer et al., 2010; Purcell et al., 2016; Wolfe \& Byrne, 2017a, b). The digestion and dissolution of carbonate sands by tropical holothuroids can also influence local biogeochemistry by increasing local alkalinity, potentially buffering against ocean acidification and enhancing reef resilience (Hammond, 1981; Schneider et al., 2011, 2013; Wolfe et al., 2018).

Corresponding author:

R. Balogh

Email: rbal8883@uni.sydney.edu.au
Many holothuroid species are harvested for the lucrative dried seafood trade, with the dried body wall product (bêche-de-mer) highly prized in the Asian market (Purcell et al., 2013, 2016; Eriksson \& Byrne, 2015; Eriksson \& Clarke, 2015). Many commercial species are in a perilous state of conservation with 16 species, largely from tropical regions, recently listed as Threatened with extinction by the International Union for Conservation of Nature (IUCN) (Purcell et al., 2013, 2014; Conand et al., 2014). At least $70 \%$ of the world's tropical holothuroid fisheries are considered exploited, over-exploited or depleted (Purcell et al., 2013), with many species now locally extinct (Hasan, 2005; Anderson et al., 2011; Branch et al., 2013; Price et al., 2013; Purcell et al., 2014).

Despite the important ecological roles of commercial holothuroids in coral reef ecosystems and their commercial value, we have a limited understanding of their reproductive cycles and spawning periodicity. These animals are iteroparous and investigation of 11 Indo-Pacific species including some of the most commercially valuable (Holothuria fuscogilva, Actinopyga mauritiana, Thelenota ananas) indicates that they spawn annually during summer (Conand, 1981, 1993a, b; Conand et al., 2002; Ramofafia et al., 2003). Spawning during winter is also documented including for 
H. whitmaei (Conand, 1981, 1993a, b; Ramofafia et al., 2000, 2001; Shiell \& Uthicke, 2006; Asha \& Muthiah, 2008). While less common, biannual spawning has been observed for H. atra in New Caledonia (Conand, 1993a, b). The timing of spawning can differ among geographically separated conspecific holothurian populations (Ramofafia et al., 2003). Holothuria scabra spawns year round in equatorial regions (Ramofafia et al., 2003), but spawns annually in higher latitude regions (Conand, 1993a, b). These differences in spawning within a species are largely restricted to populations separated by latitudinal (north-south) oriented differences (Shiell \& Uthicke, 2006). Due to the threatened status of commercial sea cucumbers, globally, we need a better understanding of their reproductive biology as a key fishery biology trait.

The curryfish, Stichopus herrmanni, is an abundant IndoPacific sea cucumber distributed from East Africa to Australia and Indonesia, which inhabits sandy lagoons, seagrass and coral reef habitats between depths of $0-30 \mathrm{~m}$ (Conand, 1993a, b; Eriksson et al., 2013; Wolfe \& Byrne, 2017a, b). Stichopus herrmanni, a mid- to low-value bêchede-mer species, has become a major harvest target as populations of higher value species continue to decline (Purcell et al., 2013, 2014; Eriksson \& Byrne, 2015). Between 2007 and 2011, curryfish catches along the Great Barrier Reef (GBR) Marine Park, increased at an average annual rate of $200 \%$ (Eriksson \& Byrne, 2015). Overall fishing pressure has resulted in a $60-90 \%$ population decline over half of the species' global range (Conand et al., 2014). Stichopus herrmanni is listed as Vulnerable to extinction by the IUCN (Purcell et al., 2014; Eriksson \& Byrne, 2015).

We investigated the reproductive biology of $S$. herrmanni at One Tree Island (OTI), southern GBR. Our current understanding of the reproduction of $S$. herrmanni is based on data obtained from a population in New Caledonia, where spawning over 5 years occurred in summer (Conand, 1993a, b). Thus far, the reproductive cycle of only two bêche-de-mer species has been determined for populations on the GBR; H. whitmaei spawns in winter and $H$. atra spawns in summer (Shiell \& Uthicke, 2006; Lee et al., 2008; Thorne et al., 2012). We determined the timing of gonad development and gamete maturation for S. herrmanni using gonad histology and the gonad index method. We also compiled observations of spawning by S. herrmanni in situ at OTI and elsewhere along the GBR and the Indo-Pacific. We hypothesized that reproduction of this species at OTI would be similar to that observed in New Caledonia (Conand, 1993a, b), as OTI and New Caledonia exist at similar latitudes. Our goal was to identify the spawning period of $S$. herrmanni at OTI and where possible, elsewhere on the GBR, providing important new information for the curryfish fishery to facilitate development of sustainable fisheries practices for this key bêche-de-mer species.

\section{MATERIALS AND METHODS}

Stichopus herrmanni (120-600 mm length) were collected from the lagoon $(2-4 \mathrm{~m}$ depth) at One Tree Island (OTI) $\left(23^{\circ} 30^{\prime} \mathrm{S} 152^{\circ} 05^{\prime} \mathrm{E}\right)$, southern GBR. Due to permit restrictions (GBR Marine Park Authority Permit G13/36027.1.) on the total number of sea cucumber species allowed to be collected annually we used data from collections over many years (Jan 2009, 2016, Feb 2011, 2013, Apr 2012, May 2009, Jul 2009,
Aug 2015, Sep 2009, Oct 2013, Nov 2008, Dec 2009). We combined data per collection month across years. To determine the gonad index, S. herrmanni were dissected and the coelomic fluid drained. The gonad index was calculated as the weight $\%$ of the gonads relative to the combined drained body wall and viscera weights. Averages were taken per month. The seasonal temperature cycle of the lagoon was determined from a long-term monitoring programme (http://data.aims.gov.au/aiemsrtds/station.html?station=131). Average daily temperatures in OTI lagoon were combined to calculate monthly averages between 2008 and $2017(\mathrm{~N}=66-$ 99 month $^{-1}$ ).

A portion of the gonad was fixed in Bouin's fluid and processed for routine wax histology. The gonad sections $(7 \mu \mathrm{m}$ thick) were stained in haematoxylin and eosin, and gonad histological condition was determined by microscopic examination. The gametogenic state of the gonads were scored in four stages: mature, partly spawned, post-spawned/spent and recovering, as in previous studies of sea cucumber gonad histology (Ramofafia et al., 2001, 2003). Digital images of gonad sections were captured using an Olympus DP7o digital camera mounted onto an Olympus BX 50 microscope. Maximum egg size in mature ovaries and the thickness of the gonad wall of testes and ovaries were determined using Image-J (NIH, Bethesda, MD, USA).

Observations of spawning of $S$. herrmanni with information of the date and time of gamete release were assimilated from personal and published observations collected at OTI, elsewhere along the GBR and at other locations in the Pacific (see Table 1). Data were assessed with respect to the lunar cycle. Based on the pattern that emerged (see Results), we undertook a targeted survey for spawning behaviour at OTI around the new moon in January 2017. On three days (28-30 January, 17:30-18:30 h) coinciding with the new moon $(\mathrm{NM}), \mathrm{NM}+1$ day and $\mathrm{NM}+2$ days, the number of spawning individuals were counted in the first $18-20$ individuals randomly encountered along two transects $(10-20 \mathrm{~m})$ along the reef edge at Shark Alley (0.5-3 m depth), OTI, on snorkel.

To determine whether the gonad index differed among months, these data were compared by one-way ANOVA, with month as the fixed factor. Percentage data were arcsine transformed before analysis using JMP 501 (Cary, NC, USA). As required for ANOVA, homogeneity of variance and normality was checked and confirmed for all data series (Quinn \& Keough, 2003). Post-hoc Tukey's HSD tests were used to determine where significant differences lay.

\section{RESULTS}

\section{Ovary histology}

Mature ovaries Stichopus herrmanni had late stage oocytes (mean diameter: $94.3 \pm 0.9 \mu \mathrm{m} ; \mathrm{N}=420$ ) filling the lumen, each located in an individual follicle (Figure $1 \mathrm{~A}, \mathrm{~B}$ ). During the mature stage the ovary wall was at its minimal thickness $(14.3 \pm 1.5 \mu \mathrm{m} ; \mathrm{N}=120)$. Partly spawned ovaries were marked by loosely packed unspawned oocytes and the presence of aggregations of phagocytes in the lumen (Figure $\left.{ }_{1} \mathrm{C}, \mathrm{D}\right)$. Overlapping generations of oocytes were present in mature and partly spawned ovaries with a renewal of gametogenesis evident along the germinal 
Table 1. Observations of Stichopus herrmanni spawning on the Great Barrier Reef between 1987 and 2016, with indication of lunar cycle (NM $=$ new moon). Data taken from: 1. Uthicke (1994); 2. Conand (1989); 3. Desurmont (2008).

\begin{tabular}{|c|c|c|c|c|}
\hline Location & Date & Time & Moon phase & Observer \\
\hline Little Broadhurst, GBR & $23 / 10 / 1987$ & 1645 & NM & \\
\hline \multirow[t]{4}{*}{ Davies Reef, GBR } & $18 / 12 / 1990$ & 1700 & $\mathrm{NM}+1$ & \\
\hline & $07 / 12 / 1991$ & 1800 & $\mathrm{NM}+1$ & \\
\hline & $08 / 12 / 1991$ & 2005 & $\mathrm{NM}+2$ & \\
\hline & $07 / 01 / 1992$ & 2050 & $\mathrm{NM}+2$ & \\
\hline \multirow[t]{2}{*}{ Lizard Island, GBR } & $25 / 11 / 1992$ & 1730 & NM & B. Kerrigan \\
\hline & $26 / 11 / 1992$ & 1740 & $\mathrm{NM}+1$ & S. Uthicke ${ }^{1}$ \\
\hline Heron Island, GBR & $23 / 12 / 2016$ & 1800 & $\mathrm{NM}-6$ & R. Sweetapple \\
\hline \multirow[t]{5}{*}{ One Tree Island, GBR } & $18 / 12 / 2009$ & - & $\mathrm{NM}+1$ & H. Eriksson \\
\hline & $22 / 01 / 2015$ & 1710 & $\mathrm{NM}+1$ & M. Kingsford \\
\hline & $19 / 02 / 2015$ & 1800 & $\mathrm{NM}+1$ & K. Wolfe \\
\hline & $28 / 01 / 2017$ & 1730 & NM & K. Wolfe, M. Byrne \\
\hline & $29 / 01 / 2017$ & 1730 & $\mathrm{NM}+1$ & K. Wolfe, M. Byrne \\
\hline- & $02 / 12 / 2013$ & - & NM & J. Gillespie \\
\hline \multirow[t]{3}{*}{ Noumea, New Caledonia } & $20 / 02 / 1980$ & - & $\mathrm{NM}+4$ & C. Conand ${ }^{2}$ \\
\hline & $07 / 01 / 2008$ & $1730-1800$ & $\mathrm{NM}-1$ & A. Desurmont ${ }^{3}$ \\
\hline & $09 / 01 / 2008$ & $1730-1800$ & $\mathrm{NM}+1$ & A. Desurmont ${ }^{3}$ \\
\hline
\end{tabular}

epithelium (Figure $1 \mathrm{C}, \mathrm{D})$. Fully mature and partly spawned gonads were observed in late spring and summer (NovFeb). The largest oocytes had a mean diameter of $101.1 \pm$ $2.8 \mu \mathrm{m}(\mathrm{N}=120)$ (Figure $1 \mathrm{~B})$.

Spent ovaries of $S$. herrmanni were largely empty and had a thick gonad wall $(27.7 \pm 2.0 \mu \mathrm{m} ; \mathrm{N}=120)$ (Figure $1 \mathrm{E}$ ). Variable numbers of relict oocytes and phagocytes were present. It appears that the unspawned eggs were broken down and reabsorbed. Recovery stage ovaries had basophilic previtellogenic oocytes developing along the germinal epithelium (Figure $1 \mathrm{~F}$ ). As the oocytes developed they became increasingly eosinophilic, indicating vitellogenesis.

\section{Testis histology}

Mature testes were packed with basophilic spermatozoa (Figure 2A, B). Infolds of the germinal epithelium were absent and the wall of the testis was at its thinnest (7.0 \pm $0.8 \mu \mathrm{m} ; \mathrm{N}=120$ ). Partly spawned testes had fewer sperm in the lumen and an increase in the thickness of the gonad wall (Figure $2 \mathrm{C}, \mathrm{D}$ ). There was evidence of renewed spermatogenesis in partly spawned testes with developing sperm present along the re-appeared folds of the germinal epithelium. Spent testes were devoid of contents, with the exception of a few unspawned spermatozoa (Figure $2 \mathrm{E}$ ) and the gonad wall was thick $(24.1 \pm 1.7 \mu \mathrm{m} ; \mathrm{N}=120)$ and had a wrinkled appearance. In recovery stage testes, developing sperm lined the germinal epithelium. The layer of developing sperm increased as the testis developed with invaginations of the germinal epithelium protruding towards the centre of the tubule, increasing the surface area of the germinal epithelium (Figure $2 \mathrm{~F}$ ).

\section{Seasonal trends in histology and the gonad index}

Gametogenesis of S. herrmanni showed a seasonal pattern (Figure 3). In both sexes, mature gametes were observed from late-spring (Nov, 25\%) through summer (Dec, 80\%; Jan, 5.6\%; Feb, 64.7\%). In summer, most S. herrmanni were mature (Figure 3). Partly spawned individuals were also present in summer, especially in January (77.8\%). Almost all $S$. herrmanni observed in autumn (April-May) and winter (July-Aug) had spent gonads. Recovery stage gonads were evident from August (55\%) through to November (75\%).

OTI lagoon has a distinct seasonal temperature cycle, with daily averages ranging from $25.2-29.4^{\circ} \mathrm{C}$ in the summer months (mean: $\mathrm{Dec}=26.7^{\circ} \mathrm{C}$, Jan $=27.3^{\circ} \mathrm{C}, \mathrm{Feb}=27.2^{\circ} \mathrm{C}$ ), to $19.4-23.9^{\circ} \mathrm{C}$ in the winter months (mean: Jun $=22.3^{\circ} \mathrm{C}$, $\mathrm{Jul}=21.2^{\circ} \mathrm{C}$, Aug $=21.2^{\circ} \mathrm{C}$ ) (Figure 4). The annual mean daily temperature was $24.4^{\circ} \mathrm{C}( \pm 0.7)$, with an average range of $19.4-29.4^{\circ} \mathrm{C}$ across the year. The gonad index of $S$. herrmanni differed between months $\left(F_{8,59}=10.16, P<\right.$ 0.0001), in parallel with water temperature (Figure 4). Tukey's HSD tests revealed that the average gonad index was highest in January $(8.26 \pm 1.4 \%)$ and February $(3.65 \pm$ $0.5 \%$ ) (Figure 4). Some S. herrmanni lacked identifiable gonads in the winter.

\section{Spawning observations}

Records from in situ observations $(\mathrm{N}=13)$ show that Stichopus herrmanni spawns from late spring (Nov) through summer (Dec-Feb) near sunset (1730-1830) (Figure 5), typically around the new moon at several sites along the GBR from the southern (One Tree Island, Heron Island), central (Little Broadhurst Reef, Davies Reef), northern (Lizard Island) GBR, and also in New Caledonia (Table 1). One spawning observation was made $\sim_{1}$ week before a new moon event in December 2016 (Table 1). As is typical of aspidochirotids, S. herrmanni adopts an erect posture during spawning (Figure 6A).

Observations of spawning by $S$. herrmanni were most frequently documented in January with additional observations in November, December and February (Figure 5). Overall, most spawning observations were recorded on the day following the new moon, as well as on the new moon and a day before the new moon. Of the months where spawning was recorded, February had the lowest number of spawning events, with only one event recorded on the day after a new 


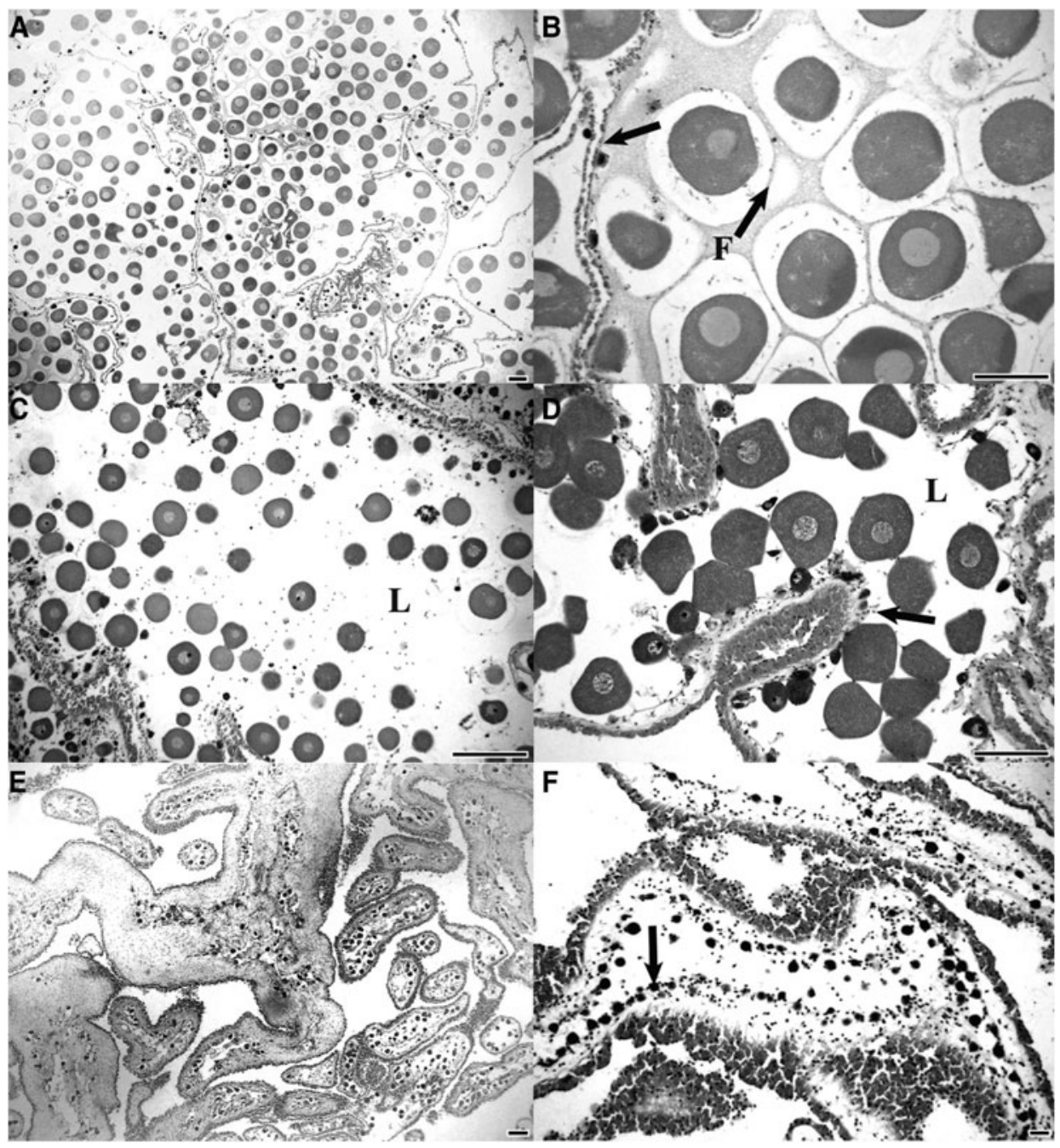

Fig. 1. Ovary histology of Stichopus herrmanni. (A, B) Mature ovary with the lumen filled with late stage oocytes within individual follicles (F). Note the thin gonad wall (arrow); (C, D) partly spawned ovary with oocytes scattered in the lumen (L) and early developing oocytes along the germinal epithelium (arrow); (E) spent ovaries with a few remaining oocytes and a thick wall; $(\mathrm{F})$ recovering ovary with a new cohort of developing oocytes along the germinal epithelium (arrows) (scale bars $=200 \mu \mathrm{m}$ ).

moon. There was a single outlier observation, a report of spawning in late October (Table 1).

In the surveys conducted at OTI on $28-29$ January 2017 (new moon and one day following) (Table 1), spawning was observed late afternoon of the NM (5/20 spawning) and $\mathrm{NM}+1$ (16/21 spawning). No spawning was observed on $\mathrm{NM}+2$ (Table 1). Males spawned before females. As sunset approached individuals were still in the process of moving to elevated positions (Figure 6A). Small fishes attacked the anterior end of spawning individuals and appeared to be consuming the released gametes (Figure 6B).

\section{DISCUSSIDN}

Stichopus herrmanni has an annual reproductive cycle at OTI, spawning from late spring through summer. This pattern, based on evidence from gonad index, gonad histology and spawning observations, is similar to that reported for this species in New Caledonia in a 5-year study (Conand, 1993a, b), at a similar latitude to the population investigated here. Summer spawning is reported for several tropical aspidochirotids, including other stichopodids (e.g. Thelonata ananas) and holothurids (e.g. Holothuria atra) (Conand, 1981, 1993a, b; Conand et al., 2002; Ramofafia et al., 2003). Although our data for elsewhere on the GBR is limited, the spawning observations suggest that $S$. herrmanni spawns during the summer in this region.

Stichopus herrmanni at OTI has an annual gametogenic cycle. Oocytes developed from late winter to summer with the fully grown oocytes evident from November, as also reported in New Caledonia (Conand, 1993a, b). The histological condition of the gonads indicated that spawning in $S$. herrmanni is partial with fully mature and partly spawned gonad tubules present throughout summer. Spawning observations also indicate that $S$. herrmanni has episodic gamete release (i.e. multiple spawning) through late-spring and summer. By April, the gonads were post-spawned and the remaining gametes appear to be reabsorbed. Resorption of unspawned gametes is a common feature of aspidochirotid and echinoderm gonads and is suggested to be associated with exogenous cues and/or an underlying endogenous rhythm (Eckelbarger \& Young, 1992; Morgan, 2000; Ramofafia et al., 2003). After the spawning period, the 


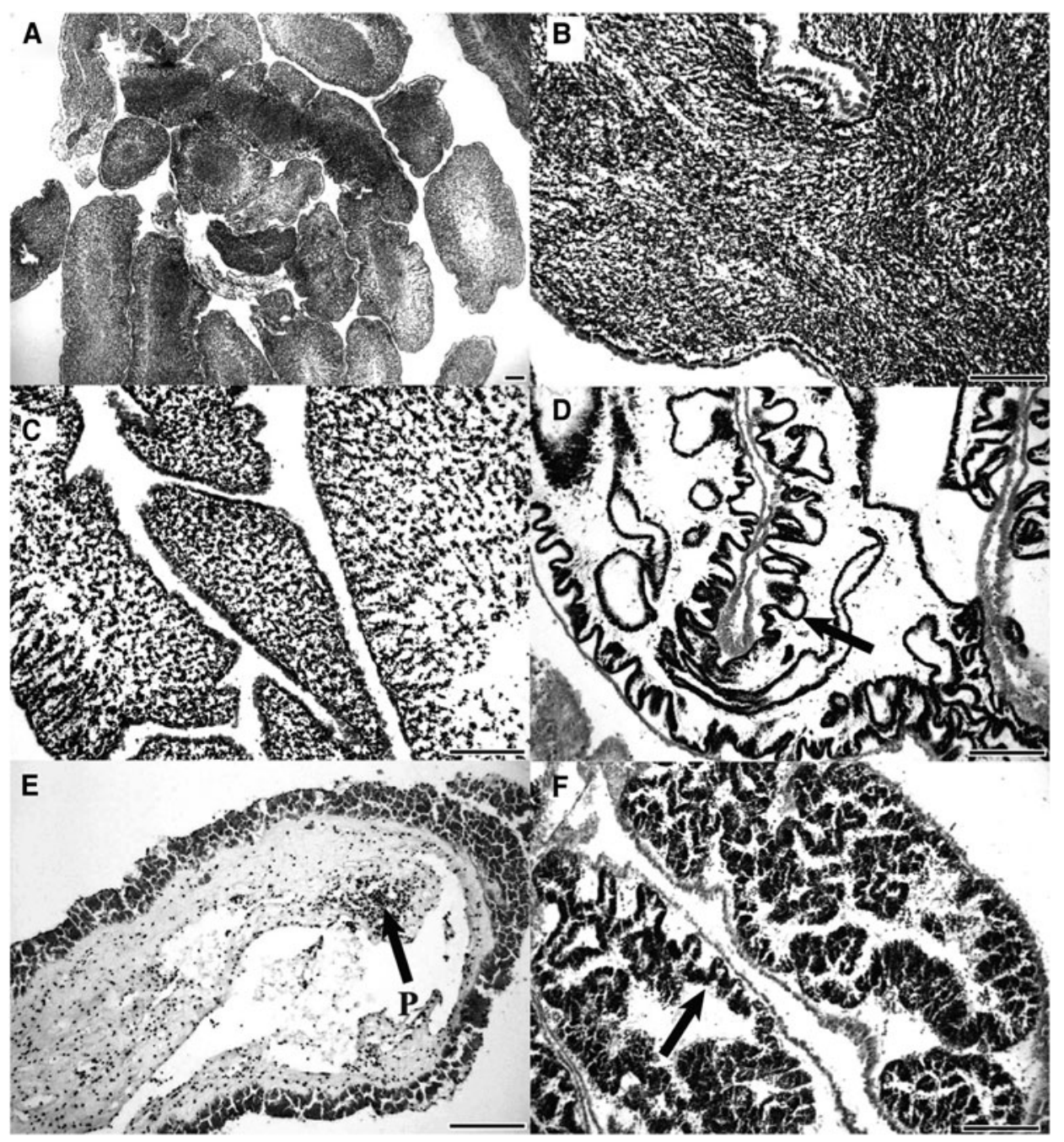

Fig. 2. Testis histology of Stichopus herrmanni. (A, B) Mature testis with the lumen filled with sperm; (C) partly spawned testis with sperm scattered in the lumen: (D, E) spent testis with an empty lumen. The folds of the germinal epithelium are evident (arrows) as are aggregations of phagocytes (P); (F) recovering testis with a new cohort of developing sperm along the folds of the germinal epithelium (scale bars $=200 \mu \mathrm{m}$ ).

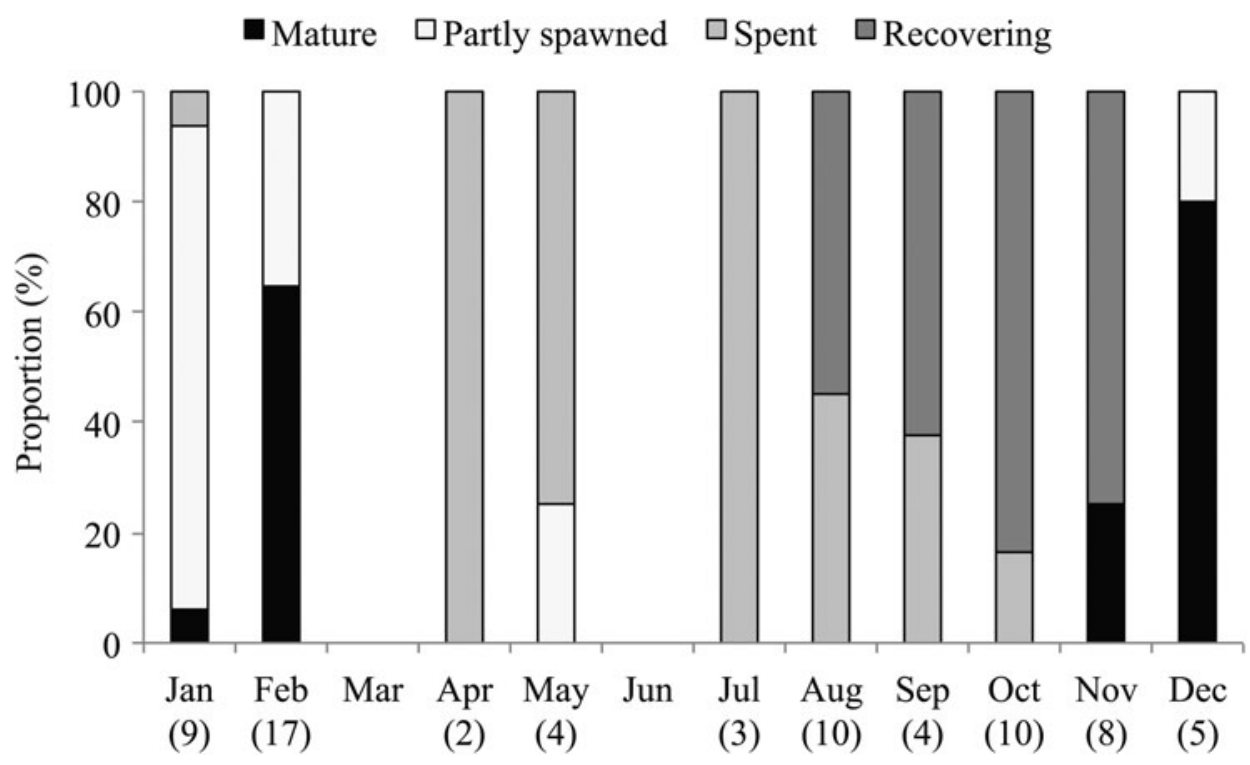

Fig. 3. Histological condition of the gonads of Stichopus herrmanni (sample size in parentheses) across the seasons. 


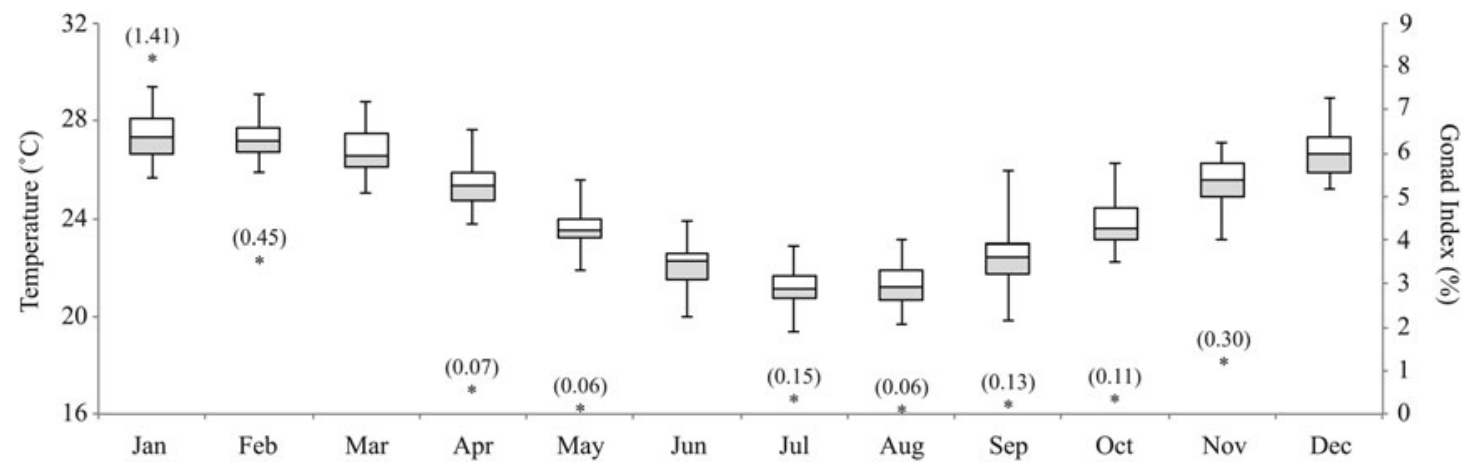

Fig. 4. Annual temperatures at One Tree Island lagoon (2008-2017) and gonad index for Stichopus herrmanni (sample size in parentheses).



Fig. 5. Number of observations of spawning of Stichopus herrmanni on the Great Barrier Reef and New Caledonia with respect to lunar cycle (NM $=$ new moon).

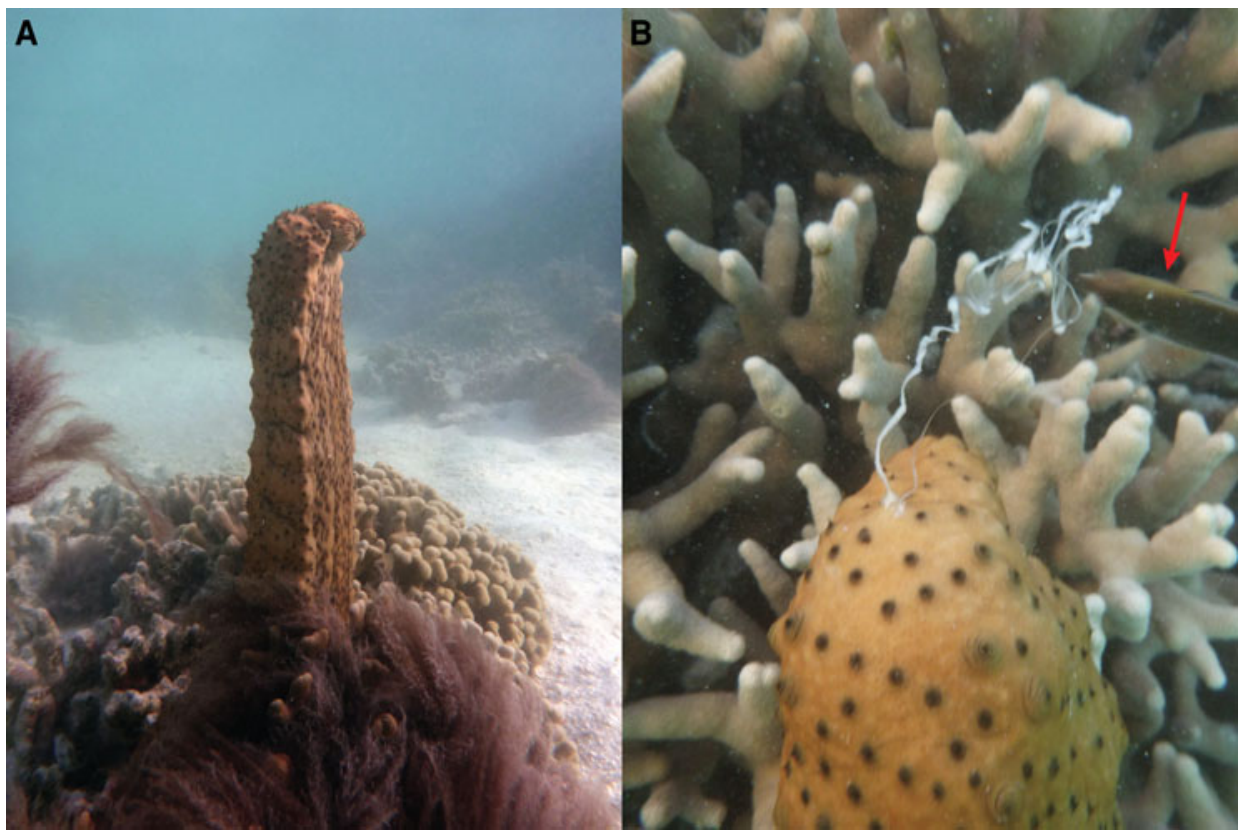

Fig. 6. Broadcast spawning behaviour of Stichopus herrmanni on One Tree Island, showing the (A) erect posture typical of spawning holothuroids and (B) sperm release. Spawning individuals attract fishes (arrow) to the released gametes. 
gonads enter a spent/resting phase with little gametogenic activity for 6 months over winter (March/April to Sept/Oct) as also reported for $S$. herrmanni in New Caledonia (Conand, 1993a, b).

Temperature, salinity, photoperiod and food availability have been suggested to regulate the process of gametogenesis in sea cucumbers (Cameron \& Fankboner, 1986; Conand, 1993a, b; Morgan, 2000; Hamel et al., 2001; Conand et al. 2002; Ramofafia et al., 2003; Shiell \& Uthicke, 2006). The gonads of $S$. herrmanni had minimum development in winter and were mature in summer, indicating gametogenesis is controlled by temperature and day length. In both temperate and tropical species, the early gametogenic phase appears to coincide with the cooler months and when days are shorter than nights, as suggested for Actinopyga mauritiana, $H$. scabra, S. californicus, Thelenota ananas (Cameron \& Fankboner, 1986; Conand, 1993a, b; Ramofafia et al., 2001). A resting phase in the winter, when the gonads are at their minimal size (or absent), is a feature described for temperate stichopodids, and is suggested to represent an aestivation-like cessation of activity due to cold conditions at high latitudes (Cameron \& Fankboner, 1986). This phenomenon is also observed for tropical species, indicating that a quiescent gonad phase may be common among aspidochirotids (Morgan, 2000; Hamel et al., 2001; Ramofafia et al., 2003).

At OTI, S. herrmanni experiences distinct seasonal temperature fluctuations $\left(\sim 10^{\circ} \mathrm{C}\right)$, and the cold season might initiate an aestivation-like response in reproductive activity. However, S. herrmanni is abundant in equatorial locations where annual temperature flux is minimal. In these regions with minimal seasonal cues, continuous reproduction is predicted for echinoderms (Giese \& Pearse, 1974) as occurs in equatorial populations of $H$. scabra (Ramofafia et al., 2003). An assessment of the reproductive cycle of low latitude populations of $S$. herrmanni would provide insight into whether a gonadal resting phase is species-specific or varies with latitude (i.e. temperature-driven). In addition to the seasonal temperature cycle, day length and lunar cycle, which are fairly predictable among years, it would also be important to consider the influence of other environmental variables such as food availability and cyclones on reproduction of $S$. herrmanni.

The onset of gonad growth occurred in late-winter (August), correlating with increasing day length. There was an overlap in spent and recovering stages of gametogenesis in the gonads of $S$. herrmanni at OTI from August to October. Gonad maturation is reached by November at OTI and New Caledonia (Conand, 1993a, b), as temperature and day length increase. Summer spawning indicates that the small individuals observed in autumn (four months later) on nearby reefs are likely to be new recruits (Wolfe \& Byrne, 2017b).

While gonad development and maturation appear to be entrained by a seasonal cycle, coinciding with the warmest temperatures and longest days, spawning and the behavioural change to move to elevated places such as coral bommies appears to be cued by the lunar cycle. This behavioural change brings individuals closer together, an aggregation-like response also observed in $H$. scabra (Morgan, 2000; Hamel et al., 2001). At OTI, S. herrmanni began moving up coral bommies before dusk and spawning started soon after, between 1645 and $2050 \mathrm{~h}$. It is likely that a more aggregated distribution and spawning continues into the night, as for $S$. chloronotus on the GBR (Babcock et al., 1992). Observations in the Solomon Islands indicate that H. scabra are normally scattered but progressively form pairs, trios and larger groups, peaking a few days before the new moon. Pheromones released by males have been shown to induce aggregation and spawning in $H$. arguinensis and sympatric holothuroids (Marquet et al., 2018). Aggregative spawning is suggested to be an evolved strategy to increase fertilization rates and reduce predation of gametes through predator satiation (Babcock et al., 1992). As for S. herrmanni, males spawn prior to females in other aspidochirotids (Babcock et al., 1992; Morgan, 2000; Hamel et al., 2001; Marquet et al., 2018). Males release sperm over long periods in contrast to the short bursts of egg release by females (Babcock et al., 1992).

The timing of spawning can differ among geographically separated conspecific holothurian populations (Ramofafia et al., 2003). The tropical sea cucumber H. scabra spawns all year round in the Solomon Islands near the equator and annually in higher latitude regions, a disparity reflecting latitudinal (north-south) differences (see review, Ramofafia et al., 2003). For H. whitmaei, spawning occurs in winter for western and eastern Australian populations at the same latitude, in the Indian and Pacific Oceans, respectively (Shiell \& Uthicke, 2006). As S. herrmanni is such a widely distributed species in the Indo-Pacific, it remains to be determined if its reproductive cycle and spawning periodicity differs across oceans and latitude.

Successful reproduction of marine invertebrates requires individuals to be in close proximity (Pakoa et al., 2014). Low population densities effectively reduce the chances of the successful fertilization, leading to reproductive failure the Allee effect (Allee, 1938). Unlike several tropical holothuroids that can reproduce asexually (e.g. H. atra, Lee et al., 2008), S. herrmanni only reproduces by sexual means. Weakened mating capacity of stocks due to overfishing leads to population declines and local extinctions with minimal population recovery, as observed for several commercial species (Uthicke et al., 2004; Hasan, 2005; Purcell, 2010; Friedman et al., 2011). Although the population density of S. herrmanni is particularly high on OTI (Eriksson et al., 2013; Wolfe \& Byrne, 2017a), which has been an unfished reef for decades, populations on reefs open to fishing are vulnerable to exploitation. There are no pre- or post-harvest data for any of the fished areas on the GBR, so the impact of removal of mature adults on reproductive success and the persistence of populations is not known. This is an urgent knowledge gap to address considering the Vulnerable status of $S$. herrmanni (Eriksson \& Byrne, 2015).

Early research on the primary high-value target bêchede-mer species on the GBR, H. whitmaei, prompted the closure of its fishery over a decade ago (Roelofs, 2004; Uthicke et al., 2004). As populations of high-value species decline, low- to mid-value species are targeted leading to a sequential pattern of depletion across the Indo-Pacific (Purcell et al., 2014; Eriksson \& Byrne, 2015; Eriksson \& Clarke, 2015). As a result, the mid-value curryfish, S. herrmanni, is now a major target species on the GBR (Eriksson \& Byrne, 2015). It is likely that the commercial exploitation of $S$. herrmanni will mimic the patterns documented for previous target species if appropriate management strategies are not implemented (Eriksson \& Byrne, 2015; Eriksson et al., 2015). Based on our data, spawning closures could be considered. At present there are no constraints on fishing throughout the year for $S$. herrmanni. Importantly, this species 
exhibits an ontogenetic migration within their recruitment reef (Eriksson et al., 2013; Wolfe \& Byrne, 2017b). This connectivity between juvenile recruitment and adult habitats highlights the vulnerability of many marine species to overfishing (Gillanders et al., 2003; Grüss et al., 2011). However, there are no data available on S. herrmanni, and many other target commercial species, on fished reefs along the GBR.

Current approaches of bêche-de-mer fisheries are extremely exploitive and are not viable for holothuroid resources (Conand et al., 2014; Purcell et al., 2012, 2013, 2014; Eriksson \& Byrne, 2015), prompting the suggestion that a paradigm shift in fisheries management is needed. Fisheries-independent information is necessary to understand the true status of the commercial fishery on the GBR, and elsewhere. This is particularly important with regard to the aggregative behaviour exhibited during spawning and the clear implications for negative Allee effects following unsustainable fishing practices.

\section{ACKNDWLEDGEMENTS}

We thank many colleagues for assistance with data collection, particularly Dr Brendan Kelaher and Dr Mel Coleman and to colleagues who provided precise information on spawning over years including Dr Mike Kingsford and Dr Hampus Eriksson. Thanks to the staff of One Tree Island Research Station, a facility of the University of Sydney. This project operated under the GBRMPA permit no. G13/36027.1.

\section{FINANCIAL SUPPORT}

This research was supported by grants from the Mohamed bin Zayed Species Conservation Fund, the Great Barrier Reef Foundation, the Great Barrier Reef Marine Park Authority, the Paddy Pallin Foundation, the Holsworth Wildlife Research Endowment and a $\mathrm{PhD}$ Scholarship from the University of Sydney.

\section{REFERENCES}

Allee W.C. (1938) The social life of animals. New York, NY: WW Norton \& Company.

Anderson S.C., Flemming J.M., Watson R. and Lotze H.K. (2011) Rapid global expansion of invertebrate fisheries: trends, drivers, and ecosystem effects. PLoS ONE 6, e14735.

Asha P.S. and Muthiah P. (2008) Reproductive biology of the commercial sea cucumber Holothuria spinifera (Echinodermata: Holothuroidea) from Tuticorin, Tamil Nadu, India. Aquaculture International 16 $231-242$.

Babcock R., Mundy C., Keesing J. and Oliver J. (1992) Predictable and unpredictable spawning events: in situ behavioural data from freespawning coral reef invertebrates. Invertebrate Reproduction and Development 22, 213-228.

Branch T.A., Lobo A.S. and Purcell S.W. (2013) Opportunistic exploitation: an overlooked pathway to extinction. Trends in Ecology and Evolution 28, 409-413.

Cameron J.L. and Fankboner P.V. (1986) Reproductive biology of the commercial sea cucumber Parastichopus californicus (Stimpson)
(Echinodermata: Holothuroidea) I. Reproductive periodicity and spawning behaviour. Canadian Journal of Zoology 64, 168-175.

Conand C. (1981) Sexual cycle of three commercially important holothurian species (Echinodermata) from the lagoon of New Caledonia. Bulletin of Marine Science 31, 523-543.

Conand C. (1989) Les Holothuries Aspidochirotes du lagon de NouvelleCalédonie: biologie, écologie et exploitation. Paris: Etudes et Thèses, ORSTOM, $393 \mathrm{pp}$

Conand C. (1993a) Ecology and reproductive biology of Stichopus variegatus, an Indo-Pacific coral reef sea cucumber (Echinodermata: Holothuroidea). Bulletin of Marine Science 52, 970-981.

Conand C. (1993b) Reproductive biology of the holothurians from the major communities of the New Caledonian Lagoon. Marine Biology $116,439-450$.

Conand C., Polidoro B.A., Mercier A., Gamboa R., Hamel J-F. and Purcell S.W. (2014) The IUCN Red List assessment of aspidochirotid sea cucumbers and its implications. SPC Bêche-de-mer Information Bulletin 34, 3-7.

Conand C., Uthicke S. and Hoareau T. (2002) Sexual and asexual reproduction of the holothurian Stichopus chloronotus (Echinodermata): a comparison between La Réunion (Indian Ocean) and east Australia (Pacific Ocean). Invertebrate Reproduction and Development 41, 235-242.

Desurmont A. (2008) Natural spawning observations. SPC Beche-de-Mer Information Bulletin 27, 42.

Eckelbarger K.J. and Young C.M. (1992) Ovarian ultrastructure and vitellogenesis in ten species of shallow-water and bathyal sea cucumbers (Echinodermata: Holothruoidea). Journal of the Marine Biological Association of the United Kingdom 72, 759-781.

Eriksson H. and Byrne M. (2015) The sea cucumber fishery in Australia's Great Barrier Reef Marine Park follows global patterns of serial exploitation. Fish and Fisheries 16, 329-341.

Eriksson H. and Clarke S. (2015) Chinese market responses to overexploitation of sharks and sea cucumbers. Biological Conservation 184, $163-173$.

Eriksson H., Conand C., Lovatelli A., Muthiga N.A. and Purcell S.W. (2015) Governance structures and sustainability in Indian Ocean sea cucumber fisheries. Marine Policy 56, 16-22.

Eriksson H., Thorne B.V. and Byrne M. (2013) Population metrics in protected commercial sea cucumber populations (curryfish: Stichopus herrmanni) on One Tree Reef, Great Barrier Reef. Marine Ecology Progress Series 473, 225-234

Eriksson H., Torre-Castro M., Eklof J. and Jiddawi N. (2010) Resource degradation of the sea cucumber fishery in Zanzibar, Tanzania: a need for management reform. Aquatic Living Resources 23, 387-398.

Friedman K., Eriksson H., Tardy E. and Pakoa K. (2011) Management of sea cucumber stocks: patterns of vulnerability and recovery of sea cucumber stocks impacted by fishing. Fish and Fisheries 12, 75-93.

Giese A.C. and Pearse J.S. (eds) (1974) Introduction: general principles. In Reproduction in marine invertebrates vol I. Acoelomate and pseudocoelomate metazoans. New York, NY: Academic Press, pp. 1-49.

Gillanders B.M., Able K.W., Brown J.A., Eggleston D.B. and Sheridan P.F. (2003) Evidence of connectivity between juvenile and adult habitats for mobile marine fauna: an important component of nurseries. Marine Ecology Progress Series 247, 281-295.

Grüss A., Kaplan D.M., Guénette S., Roberts C.M. and Botsford L.W. (2011) Consequences of adult and juvenile movement for marine protected areas. Biological Conservation 144, 692-702.

Hamel J-F., Conand C., Pawson D.L. and Mercier A. (2001) The sea cucumber Holothuria scabra (Holothuroidea: Echinodermata): its 
biology and exploitation as bêche-de-mer. Advances in Marine Biology 41, 129-223.

Hammond L.S. (1981) An analysis of grain size modification in biogenic carbonate sediments by deposit-feeding holothurians and echinoids (Echinodermata). Limnology and Oceanography 26, 898-906.

Hasan M.H. (2005) Destruction of a Holothuria scabra population by overfishing at Abu Rhamada Island in the Red Sea. Marine Environmental Research 60, 489-511.

Lee J., Byrne M. and Uthicke S. (2008) The influence of population density on fission and growth of Holothuria atra in natural mesocosms. Journal of Experimental Marine Biology and Ecology 365, 126-135.

Lee S., Ferse S., Ford A., Wild C. and Mangubhai S. (2017) Effect of sea cucumber density on the health of reef-flat sediments. In Mangubhai S., Lalavanua W. and Purcell S.W. (eds) Fiji's sea cucumber fishery: advances in science for improved management. Report No. 01/17. Suva, Fiji: Wildlife Conservation Society, pp. 54-61.

Marquet N., Hubbard P.C., da Silva J.P., Afonso J., Canario A.V.M. (2018) Chemicals released by male sea cucumber mediate aggregation and spawning behaviours. Scientific Reports 8, 239.

Morgan A. (2000) Aspects of the reproductive cycle of the sea cucumber Holothuria scabra (Echinodermata: Holothuroidea). Bulletin of Marine Science 66, 47-57.

Pakoa K., Masu R., Teri J., Lequata J., Tua P., Fisk D. and Bertram I. (2014) Solomon Islands sea cucumber resource status and recommendations for management. Noumea, New Caledonia: Secretariat of the Pacific community. 6o pp

Price A.R.G., Evan L.E., Rowlands N. and Hawkins J.P. (2013) Negligible recovery in Chagos holothurians (sea cucumbers). Aquatic Conservation 23, 811-819.

Purcell S.W. (2010) Managing sea cucumber fisheries with an ecosystem approach. FAO Fisheries and Aquaculture Technical Paper No. 520. Rome: FAO.

Purcell S.W., Conand C., Uthicke S. and Byrne M. (2016) Ecological roles of exploited sea cucumbers. Oceanography and Marine Biolog $54,367-386$.

Purcell S.W., Mercier A., Conand C., Hamel J-F., Toral-Granda M.V., Lovatelli A. and Uthicke S. (2013) Sea cucumber fisheries: global analysis of stocks, management measures and drivers of overfishing. Fish and Fisheries 14, 34-59.

Purcell S.W., Polidoro B.A., Hamel J-F., Gamboa R.U. and Mercier A. (2014) The cost of being valuable: predictors of extinction risk in marine invertebrates exploited as luxury seafood. Proceedings of the Royal Society B 281, 20133296.

Purcell S.W., Samyn Y. and Conand C. (2012) Commercially important sea cucumbers of the world. FAO Species Catalogue for Fisheries Purposes. No. 6. Rome: FAO, 150 pp.

Quinn G. and Keough M. (2003) Experimental design and data analysis for biologists. Cambridge: Cambridge University Press.

Ramofafia C., Battaglene S.C., Bell J.D. and Byrne M. (2000) Reproductive biology of the commercial sea cucumber Holothuria fuscogilva in the Solomon Islands. Marine Biology 136, 1045-1056.

Ramofafia C., Byrne M. and Battaglene S.C. (2001) Reproductive biology of the intertidal sea cucumber Actinopyga mauritiana in the Solomon Islands. Journal of the Marine Biological Association of the United Kingdom 81, 523-531.

Ramofafia C., Byrne M. and Battaglene S.C. (2003) Reproduction of the commercial sea cucumber Holothuria scabra (Echinodermata: Holothuroidea) in the Solomon Islands. Marine Biology 142, 281-288.

Roelofs A. (2004) Ecological assessment of the Queensland's East Coast Bêche-de-mer fishery. A report to the Australian Government
Department of Environment and Heritage on the ecological sustainable management of a highly selective dive fishery. Queensland Government of Department of Primary Industries. Available at: https://www.environment.gov.au/system/files/pages/36ccoo69-68734f59-a5aa-ooc818e22d3o/files/east-coast-beche-de-mer-submission. pdf.

Schneider K., Silverman J., Kravitz B., Rivlin T., Schneider-Mor A., Barbosa S., Byrne M. and Caldeira K. (2013) Inorganic carbon turnover caused by digestion of carbonate sands and metabolic activity of holothurians. Estuarine, Coastal and Shelf Science 133, 217-223.

Schneider K., Silverman J., Woolsey E., Eriksson H., Byrne M. and Caldeira K. (2011) Potential influence of aspidochirotid sea cucumbers on coral reef $\mathrm{CaCO}_{3}$ budget: a case study at One Tree Reef. Journal of Geophysical Research 116, G04032.

Shiell G.R. and Uthicke S. (2006) Reproduction of the commercial sea cucumber Holothuria whitmaei (Holothuroidea: Aspidochirotida) in the Indian and Pacific Ocean regions of Australia. Marine Biology 148, 973-986.

Thorne B.V., Eriksson H. and Byrne M. (2012) Long term trends in population dynamics and reproduction in Holothuria atra (Aspidochirotida) in the southern Great Barrier Reef; the importance of asexual and sexual reproduction. Journal of the Marine Biological Association of the United Kingdom 93, 1067-1072.

Uthicke S. (1994) Spawning observations from the Lizard Island Area. SPC Beche-de-Mer Information Bulletin 6, 12-14.

Uthicke S. (1999) Sediment bioturbation and impact of feeding activity of Holothuria (Halodeima) atra and Stichopus chloronotus, two sediment feeding holothurians, at Lizard Island, Great Barrier Reef. Bulletin of Marine Science 64, 129-141.

Uthicke S. (2001) Nutrient regeneration by abundant coral reef holothurians. Journal of Experimental Marine Biology and Ecology 265, $153-170$.

Uthicke S. and Klumpp D.W. (1998) Microphytobenthos community production at a near-shore coral reef: seasonal variation and response to ammonium recycled by holothurians. Marine Ecology Progress Series $169,1-11$.

Uthicke S., Welch D. and Benzie J.A.H. (2004) Slow growth and lack of recovery in overfished holothurians on the Great Barrier Reef: evidence from DNA fingerprints and repeated large-scale surveys. Conservation Biology 18, 1395-1404.

Wolfe K. and Byrne M. (2017a) Biology and ecology of the vulnerable holothuroid, Stichopus herrmanni, on a high-latitude coral reef on the Great Barrier Reef. Coral Reefs 36, 1143-1156.

Wolfe K. and Byrne M. (2017b) Population biology and recruitment of the vulnerable sea cucumber, Stichopus herrmanni, on a protected reef. Marine Ecology 38, e12397.

Wolfe K., Vidal-Ramirez F., Dove S., Deaker D. and Byrne M. (2018) Altered sediment biota and lagoon habitat carbonate dynamics due to sea cucumber bioturbation in a high-pCO2 environment. Global Change Biology 24, 465-480.

and

Wolkenhauer S.M., Uthicke S., Burridge C., Skewes T. and Pitcher R. (2010) The ecological role of Holothuria scabra (Echinodermata: Holothuroidea) within subtropical seagrass beds. Journal of the Marine Biological Association of the United Kingdom 90, 215-223.

\section{Correspondence should be addressed to:}

R. Balogh School of Medical Sciences, The University of Sydney, Sydney, NSW 2006, Australia email: rbal8883@uni.sydney.edu.au 